\title{
Forecast of COVID-19 cemetery land needs with system dynamics modeling
}

\author{
Bondan Prakoso $^{1 *}$, I Dewa Ketut Kerta Widana ${ }^{1}$, Rudy Pramono ${ }^{1}$, Ernalem Bangun ${ }^{1}$, and Hafizh Surya Islami ${ }^{1}$ \\ ${ }^{1}$ Disaster Management Study Program, National Security Faculty, Republic of Indonesia Defense University. \\ IPSC Sentul Area, Bogor, West Java, Indonesia
}

\begin{abstract}
As of June 30, 2021, Indonesia ranks third in Asia with the highest number of deaths due to COVID-19. One of the provinces in Indonesia, Central Java, is ranked third nationally in the accumulation of positive cases, recoveries, and deaths. Fulfilling the need for burial grounds for COVID-19 positive bodies needs attention because several countries and regions in Indonesia were experiencing a COVID-19 public cemetery land crisis. Sragen Regency is one area in Central Java designated as a red zone. The number of death cases is relatively high needs to ensure the availability of COVID-19 burial grounds. Therefore, this study aims to model the forecast for COVID-19 burial grounds. The approach used in this research is systems thinking, while the method used is system dynamics with Powersim software. Reference data for modeling is obtained from the http://corona.sragenkab.go.id page. The simulation results show the AME value of $4.7 \%$ or less than $5 \%$ so that the model is declared valid. Based on the Business as Usual (BAU) simulation, in the 20th week, it is estimated that there will be 320 deaths with a burial area of $961.13 \mathrm{~m}^{2}$. Until the 20th week, the increase in COVID-19 Positive Population, Death, and Cemetery Land Needs on the graph of the BAU simulation results shows an exponential growth trend.
\end{abstract}

\section{Introduction}

One of Indonesia's national goals stated in the preamble to the 1945 Constitution is to protect the entire Indonesian nation and the entire homeland of Indonesia. This condition cannot be separated from the development of the strategic environment, which generally shows increasingly escalating and complex symptoms on a global scale [1]. These conditions allow the arrival of various threats, military threats (armed and unarmed), non-military threats, and hybrid threats[1]. Furthermore, the source of the threat can come from within or outside the country and is carried out by state and non-state actors, whether national, regional, or international. One of the non-military threats that hit Indonesia in disaster.

Indonesia is the largest archipelagic country in the world, consisting of more than 17,508 islands. With a beach length of $81,000 \mathrm{~km}$, this area has a population of about 268 million people, making it the fourth most populous country in the world [2]. Known as the emerald of the equator, Indonesia has extraordinary beauty and natural wealth. However, Indonesians must also be aware that they live in areas that are at high risk of disaster threats [3].

In addition to being surrounded by three main active tectonic plates, Indonesia also has 127 active volcanoes known as the ring of fire. These active tectonic and volcanic processes cause Indonesia to frequently experience earthquakes, tsunamis, volcanic eruptions, and other natural phenomena. For example, the major disaster that hit Indonesia was the 2004 Aceh earthquake and tsunami. In addition, hydrometeorological factors also triggered other natural disasters, such as flash floods, landslides, hurricanes, and tidal waves. The large Population and the large potential for multiple disasters are quite a challenge for Indonesia.

In addition to natural disasters, other disaster risks hit Indonesia, namely social and non-natural disasters. At the beginning of 2020, the world has been hit by a non-natural disaster caused by a virus, namely COVID-19, and Indonesia is no exception. The first COVID-19 was reported in Indonesia on March 2, 2020, in several two cases announced by President Jokowi and Minister of Health Terawan Agus Putranto. With the issuance of Presidential Decree No. 12 of 2020, on April 13, 2020, the Government of Indonesia declared COVID-19 a national disaster because its scale was so massive. As of June 29, 2021 , cumulatively, there were $2,156,465$ positive cases, $1,869,606$ recovered cases, and 58,024 deaths (Covid19.go.id), with a significant increase in cases occurring after Lebaran 2021. This increase in cases cannot be separated from the inclusion of several new variants introduced from other countries, for example, the

* Corresponding author : bondanhootowl@gmail.com 
Delta variant from India. Compared to other less populous countries, the dense Population in Indonesia is expected to impact and suffer for a longer time [4]. The trend of positive confirmed cases of COVID-19 in Indonesia can be seen in Fig. 1.

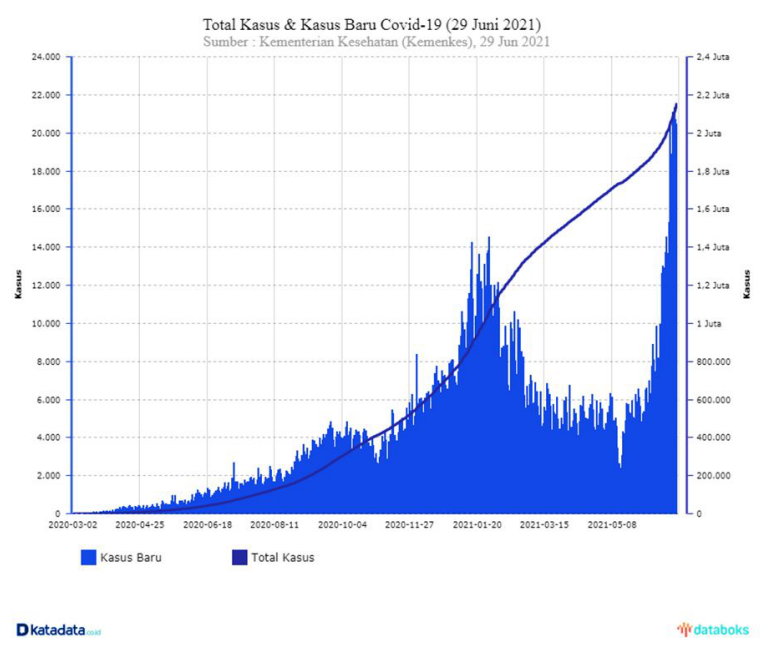

Fig. 1. Trends in COVID-19 Positive Confirmed Cases in Indonesia [5]

COVID-19 is a serious disruption to the functioning of multidimensional aspects of Indonesian people's lives. COVID-19 has disrupted the state of Indonesia, national security, and human security. Therefore, COVID-19 is designated as a non-natural disaster because it negatively impacts the form of death and other adverse impacts. When compared to COVID-19 deaths in Asia as of June 30, 2021, Indonesia ranks third after India and Iran. The comparison graph of these mortality trends is illustrated in Fig. 2.

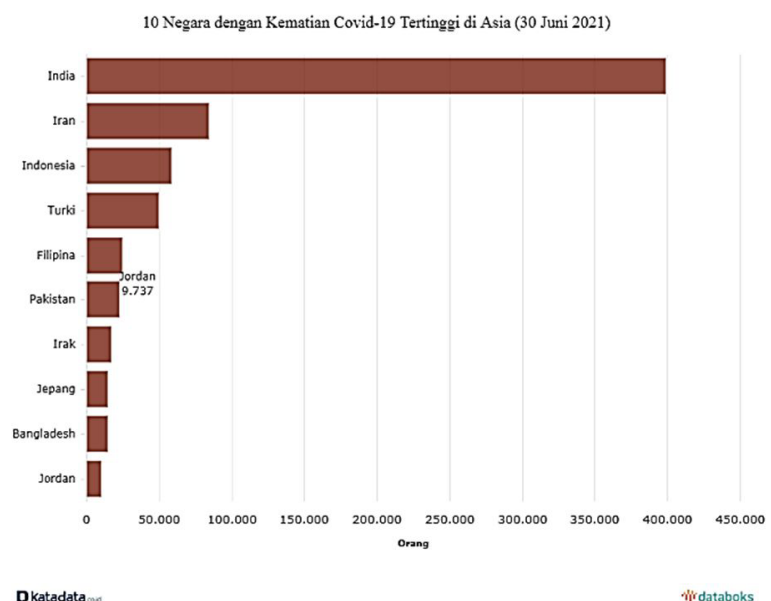

Fig. 2. Comparison of the 10 Countries with the Highest COVID-19 Deaths in Asia [5]

One of the provinces in Indonesia that have been affected by COVID-19 is Central Java. Based on data obtained from the https://corona.jatengprov.go.id page, the number of COVID-19 cases in Central Java Province as of June 29, 2021, was 251,604 positive cases, 212,386 recovered cases, and 16,082 deaths. These data put Central Java Province in the third-highest rank after DKI Jakarta and West Java. In addition, almost all districts/cities in Central Java have a high risk of transmission of COVID-19 or red zones. The areas in question are Brebes Regency, Cilacap Regency, Tegal Regency, Pemalang Regency, Pekalongan City, Pekalongan Regency, Batang Regency, Banjarnegara Regency, Kebumen Regency, Kendal Regency, Semarang City, Semarang Regency, Purworejo Regency, Magelang Regency, Demak Regency, Jepara Regency, Kudus Regency, Pati Regency, Grobogan Regency, Sragen Regency, Sukoharjo Regency, Karanganyar Regency, Wonogiri Regency, Rembang Regency, Blora Regency, and Sragen Regency. The map of the risk of COVID-19 transmission in Central Java can be seen in Fig. 3.

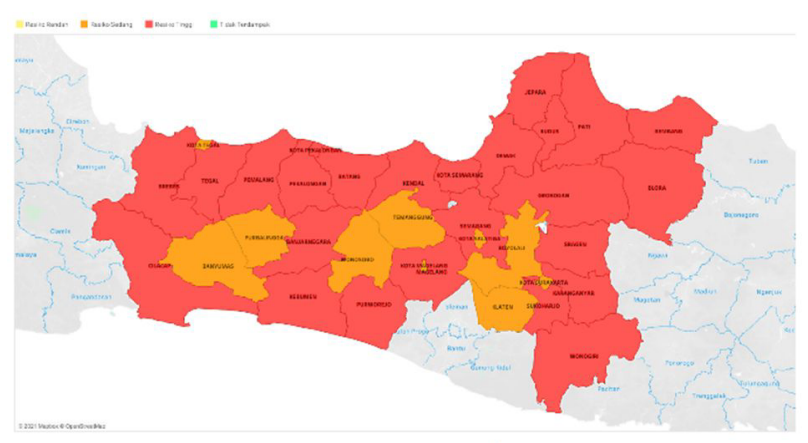

Fig. 3. Map of COVID-19 Transmission Risk in Central Java

Sragen Regency is one of the areas in Central Java that is designated as a red zone. Based on data as of June 29, 2021, Sragen Regency is ranked sixth in Central Java with an accumulation of 9,059 positive confirmed cases, 1,106 active cases, 7,268 recovered cases, and 685 cases died.

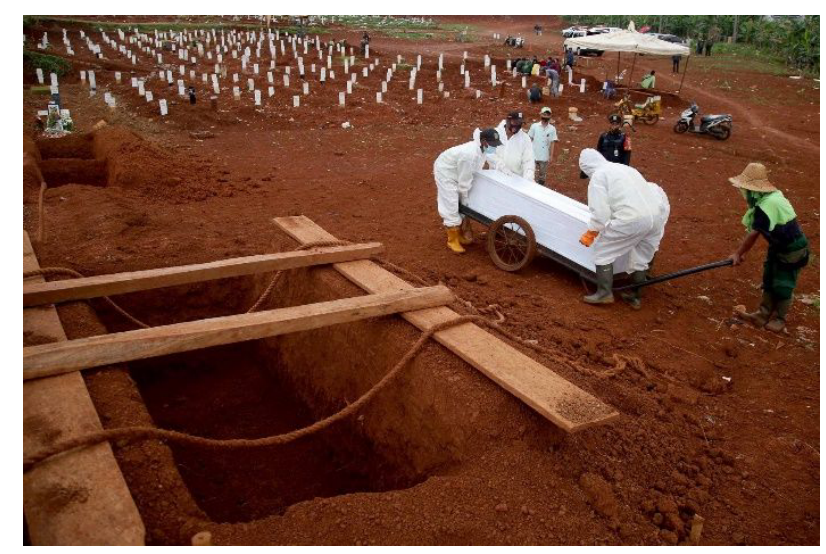

Fig. 4. Conditions of the Pondok Ranggon COVID-19 Public Cemetery in Jakarta

An interesting thing to research related to COVID-19 is the fulfillment of the need for burial grounds. For example, India is experiencing a crisis of cemeteries and crematoriums being overwhelmed by the number of deaths. Cemeteries are running out of space in many cities and funeral cremation fires burn through the night [6]For example, in Indonesia, the Pondok Ranggon COVID-19 public cemetery has experienced a severe crisis since 
November 8, 2020, and all COVID-19 graves are full. To accommodate more bodies, funeral parlors began placing more than one body into graves. This policy only applies if the corpse is a close family member recorded on the same Family Card (KK) [7]. The condition of the Pondok Ranggon COVID-19 public cemetery can be seen in Fig. 4.

As the province with the third-highest number of positive cases in Indonesia, Central Java Province also needs to prepare burial grounds for cases of deaths due to COVID-19. Therefore, the Circular Letter of the Governor of Central Java Number 443.5/0007521 was issued on Thursday, April 17, 2020. The circular letter aims to ensure the availability of burial grounds for the bodies of victims of COVID-19. Sragen Regency, as one of the areas in Central Java with a relatively high number of deaths, needs to ensure the availability of COVID-19 burial grounds. In ensuring the availability of burial grounds, local governments need to make fast, precise, and effective policies. Do not let there be a crisis related to the availability of burial grounds due to unplanned policies. Aspects of policy and governance are a serious concern because COVID-19 has resulted in crises in both aspects in various countries.

Specifically in Indonesia, when COVID-19 emerged, policymakers showed a non-serious attitude and instead made humor. This resulted in minimal anticipation efforts. In addition, various preventive equipment, especially detection equipment and personal protective equipment, were lacking when COVID-19 had not yet spread. Rapid data assessment or analysis is needed because knowledge about COVID-19 is not sufficient [8]. As an anticipatory measure, an assessment of the basis for policymaking in handling COVID-19, especially for the provision of burial grounds, needs to be carried out. Therefore, this study aims to estimate the need for COVID-19 burial grounds.

To obtain an overview of the estimated demand for COVID-19 burial areas, system dynamics modeling is used to obtain trends in death cases and the required burial area. The data needed for the modeling is data on positive cases and data on causes of death. The data on positive cases and death cases used in this study is data on the development of COVID-19 in Sragen Regency, which was taken from the http://corona.sragenkab.go.id page with the accumulation of cases in units each week.

\section{Research Methods}

The approach used in this research is systems thinking. Systems thinking is an effort to think by placing an event or problem that does not stand alone but has a relationship with other events or problems [9]. There are three processes in systems thinking, namely synthesis, dynamic, and stochastic. Meanwhile, the method used is system dynamics. In systems thinking, the dynamic character means that all elements or sub-systems will experience changes based on time.

There are five stages in the systems thinking method. First, map the problem. Second, create a causal loop model. Third, perform dynamic modeling. Fourth, modeling and designing scenarios. Fifth, implementation and organizational learning [10].

Modeling in system dynamics requires software. By using software, the behavior of the model being created can be quickly identified. In this study, the software used is the Powersim program. Powersim is a program that can be used to simulate a dynamic model. In addition, Powersim can also simulate complex models in the real world [9].

\section{Results and Discussion}

Based on the method that has been described, there are five stages in the systems thinking method, including system dynamics. Therefore, the results and discussion in this study are described in 11 sub-chapters which are divided into these five stages. Problem mapping is described in-story modeling, modeling objectives, variables used in modeling, and definitions of operational variables. After the problem is mapped, it is then made into a causal loop diagram. Then, proceed with dynamic modeling in variable equations, stock-flow diagrams, and modeling assumptions. Scenario modeling and design are realized in simulations, validations, and business as usual simulations. Finally, implementation and organizational learning are carried out by making presentations in seminars or publishing in scientific journals. In more detail, the following is an explanation.

\subsection{Modeling Story}

The unit of time used in this modeling is per week, while the unit used in the population aspect is people. The need for COVID-19 Cemetery in Sragen Regency can be calculated by multiplying the number of deaths by the area of the cemetery per person. Death is obtained by multiplying the COVID-19 Positive Population with the COVID-19 Death Rate. The Positive COVID-19 Population is obtained from the multiplication between the Weekly Population with the COVID-19 Positive Rate. Meanwhile, the number of residents per week is obtained from the number of residents multiplied by the population growth rate. Population data is obtained from Sragen Regency data in figures for [11]. The Population Growth Rate is obtained from the division of the population growth rate of Sragen Regency in Figures in 2020 into units per week.

Table 1. Reference Data

\begin{tabular}{|c|c|c|}
\hline Week- & $\begin{array}{c}\text { Residents Positive } \\
\text { COVID-19 }\end{array}$ & Death \\
\hline 1 & 313 & 20 \\
\hline 2 & 493 & 14 \\
\hline 3 & 303 & 17 \\
\hline 4 & 202 & 16 \\
\hline 5 & 219 & 13 \\
\hline
\end{tabular}

The COVID-19 Death Rate is obtained from comparing the average reference data for deaths due to COVID-19 and the average reference data for COVID-19 positive residents. Meanwhile, the COVID-19 Positive 
Number was obtained from comparing the Total Population and the average COVID-19 Positive Population reference data per week obtained from the official website http://corona.sragenkab.go.id. The reference data for COVID-19 Positive Population and COVID-19 Deaths used in this study can be seen in Table 1.

\subsection{Modeling Purpose}

The purpose of this modeling is to find out the need for burial land in Sragen Regency for the next 20 weeks using system dynamics modeling with Powersim software.

\subsection{Variables Used in Modeling}

Based on the problem story, the main components or variables used for system dynamics modeling are:

- Total Population;

- Population Growth Numbers;

- Population Growth Rate;

- Total Population Per Week;

- COVID-19 Positive Numbers;

- COVID-19 Positive Rate;

- Residents Positive COVID-19;

- COVID-19 Death Rate;

- Death;

- Cemetery Land Needs; and

- Cemetery Area Per Person.

\subsection{Definition Operational of Variable}

Based on the main components or variables used for system dynamics modeling, the operational definition of each variable is explained as follows.

- Total Population is the number of residents calculated through the population census in years. The Population of the Sragen Regency based on the 2020 Census is 890.518 people.

- Population Growth Numbers is a number that shows the percentage of population growth in one week. In this modeling, the Population Growth Rate is $0,00583 \%$ per week.

- Population Growth Rate is a number that shows the development of the Population and is obtained from the multiplication of the Population with the population growth rate.

- Total Population Per Week is the number of residents calculated through the population census in the year plus the increase in Population per week. Total Population Per Week is obtained from the multiplication between Total Population and Population Growth Rate.

- COVID-19 Positive Number is data in the form of several positive cases of COVID-19 per week, as shown in Table 1.

- COVID-19 Positive Rate is a number that shows the development of positive cases of COVID-19 and is obtained from the multiplication of the Number of
Population Per Week with the Positive Number of COVID-19.

- Residents Positive COVID-19 are residents who are confirmed positive for COVID-19 based on PCR testing. The positive Population is obtained from the multiplication of the Number of Population Per Week with the Positive Rate of COVID-19.

- COVID-19 Death Rate is the death rate due to COVID-19 based on comparing the number of deaths per week with the COVID-19 Positive Population.

- Death is COVID-19 Positive Resident who died. Death is obtained by multiplying the COVID-19 Positive Population with the COVID-19 Death Rate.

- Cemetery Land Needs is the size of the tomb required for a certain period. In this model, the unit of the time interval is weeks.

- Cemetery Area Per Person is the standard length and width of the tomb per person. In this model, the area of the tomb is 1.5 meters multiplied by 2.5 meters or $3.75 \mathrm{~m}^{2} /$ person.

\subsection{Causal Loop Diagram}

Based on the variables that have been defined, the relationship between variables is explained in the form of a Causal Loop Diagram (CLD) structure as can be seen in Fig. 6.

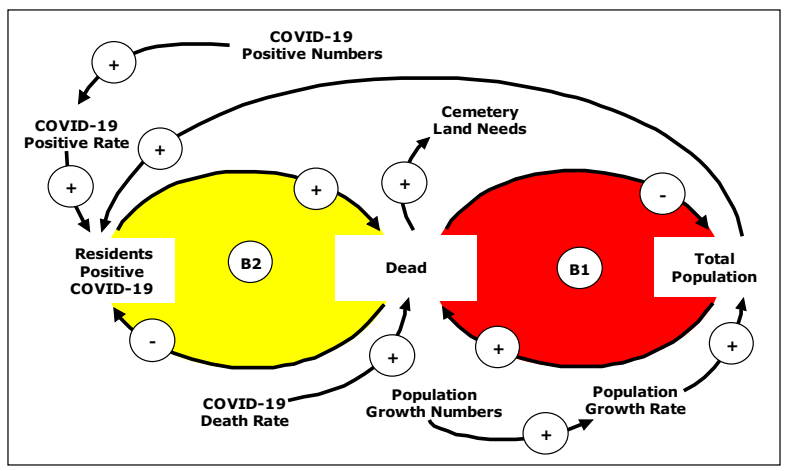

Fig. 6. Causal Loop Diagram

Based on Fig. 1, there are loops in the CLD structure. The loop in question, i.e. Population increases Death, while Death reduces Population. This loop is included in the type of balancing (B) because the multiplication between the relationship $(+)$ with (-) produces the form (). The second loop, namely COVID-19 Positive Population adds Death, while Death reduces COVID-19 Positive Population. The loop type of the second case is the same as the first loop, namely balancing.

\subsection{Variable Equation}

The variables contained in the CLD are then realized in the form of a Stock Flow Diagram (SFD). However, before making SFD, it is necessary to group the types of variables based on their symbols, values, and units. The grouping of variables based on the three models is shown in Table 2. 
Table 2. Equation of Variables in Stock Flow Diagrams

\begin{tabular}{|c|c|c|c|}
\hline Variable & Symbol & Value & Unit \\
\hline $\begin{array}{c}\text { Total } \\
\text { Population }\end{array}$ & & 890518 & People \\
\hline $\begin{array}{c}\text { Population } \\
\text { Addition } \\
\text { Rate }\end{array}$ & & 0,00583 & $\% /$ week \\
\hline $\begin{array}{c}\text { Population } \\
\text { Growth } \\
\text { Rate }\end{array}$ & & $\begin{array}{c}\text { ('Total } \\
\text { Population'* } \\
\text { 'Population } \\
\text { Growth } \\
\text { Numbers')- } \\
\text { Death } \\
\end{array}$ & $\begin{array}{c}\text { People/ } \\
\text { week }\end{array}$ \\
\hline $\begin{array}{c}\text { Weekly } \\
\text { Population }\end{array}$ & & 890518 & People \\
\hline $\begin{array}{c}\text { COVID-19 } \\
\text { Positive } \\
\text { Numbers }\end{array}$ & & 0,034362 & $\% /$ week \\
\hline $\begin{array}{c}\text { COVID-19 } \\
\text { Positive } \\
\text { Rate }\end{array}$ & & $\begin{array}{c}\text { 'Weekly } \\
\text { Population'* } \\
\text { ' COVID-19 } \\
\text { Positive } \\
\text { Numbers' }\end{array}$ & $\begin{array}{c}\text { People/ } \\
\text { week }\end{array}$ \\
\hline $\begin{array}{c}\text { COVID-19 } \\
\text { Positive } \\
\text { Residents } \\
\end{array}$ & & 313 & People \\
\hline $\begin{array}{l}\text { COVID-19 } \\
\text { Death Rate }\end{array}$ & & 5,2287582 & \%/week \\
\hline Death & & $\begin{array}{c}\text { 'Population } \\
\text { Positive } \\
\text { COVID- } \\
19{ }^{*} \text { ' } \\
\text { COVID-19 } \\
\text { Death Rate' }\end{array}$ & $\begin{array}{c}\text { People/ } \\
\text { week }\end{array}$ \\
\hline $\begin{array}{c}\text { Cemetery } \\
\text { Land } \\
\text { Needs }\end{array}$ & & $\begin{array}{c}\text { Death*' } \\
\text { Cemetery } \\
\text { Area Per } \\
\text { Person' }\end{array}$ & $\mathrm{m}^{2} /$ week \\
\hline $\begin{array}{c}\text { Cemetery } \\
\text { Area Per } \\
\text { Person }\end{array}$ & & 3,75 & $\begin{array}{c}\mathrm{m}^{2} / \text { Peop } \\
\text { le }\end{array}$ \\
\hline
\end{tabular}

\subsection{Stock Flow Diagram}

Based on the CLD along with the variable equations, symbols, values, and units, a flow chart or Stock Flow Diagram (SFD) is drawn up. The SFD that will be used to simulate COVID-19 Positive Population, Mortality, and Cemetery Land Needs is shown in Fig. 7.

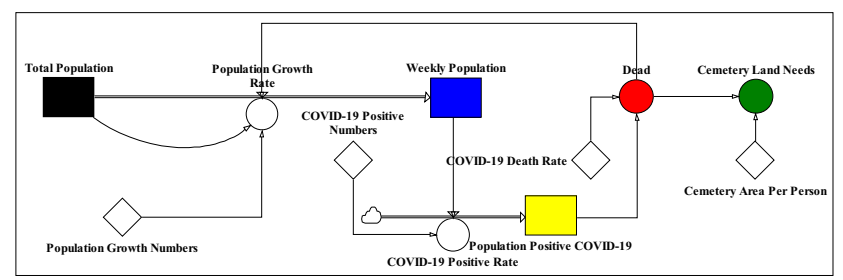

Fig. 7. Stock Flow Diagram

The variables contained in the SFD are more than the variables contained in the CLD because the calculation of
Cemetery Land Needs requires additional other variables so that the results are valid, namely Population Each Week and Cemetery Area Per Person.

\subsection{Modeling Assumptions}

To clarify the model to be made, model assumptions are needed. The assumptions of the model in question include the following.

- The cemetery area per person includes the distance between graves.

- All people in the Death Count are the same size, which is $1.5 \times 2.5$ meters or $3.75 \mathrm{~m}^{2}$.

- Cemetery Land Needs in the form of accumulation of one district so that it is not broken down by subdistrict/village/hamlet/RW/RT.

- All cases of Death are carried out by burial, not cremation or other means.

- The causative factors are not taken into consideration in determining the Active Rate, Recovery Rate, and Death Rate.

- Positive cases of COVID-19 are actively treated and the number of cures is not simulated.

\subsection{Simulation Results}

Based on the input values and units to the SFD, a simulation is carried out to produce timetables and graphs. The simulation results of the number of deaths and the need for burial ground can be seen in Table 3 .

Table 3. Simulation Data

\begin{tabular}{|c|c|c|}
\hline Week- & $\begin{array}{c}\text { Residents Positive } \\
\text { COVID-19 }\end{array}$ & Death \\
\hline 1 & 313 & 16 \\
\hline 2 & 619 & 32 \\
\hline 3 & 925 & 48 \\
\hline 4 & 1231 & 64 \\
\hline 5 & 1537 & 80 \\
\hline
\end{tabular}

\subsection{Validation}

Table 4. Reference Data and Simulation for Validation

\begin{tabular}{|c|c|c|}
\hline Week- & $\begin{array}{c}\text { Death } \\
\text { (Reference) } \\
\text { (A) }\end{array}$ & $\begin{array}{c}\text { Death } \\
\text { (Simulation) } \\
\text { (B) }\end{array}$ \\
\hline 1 & 20 & 16 \\
\hline 2 & 34 & 32 \\
\hline 3 & 51 & 48 \\
\hline 4 & 67 & 64 \\
\hline 5 & 80 & 80 \\
\hline Mean & 50,4 & 48 \\
\hline
\end{tabular}

To measure the suitability between the simulation data and the reference data, validation is needed. Validation was carried out by calculating the average mortality from the simulation results (B) and the average mortality from the reference data (A). The data and the average of the two types of Death Case data can be seen in Table 4. 
Testing the validity of the simulation results can use the Absolute Means Error (AME) formula. The maximum acceptable fault tolerance limit with the AME test. The model is valid if the AME is less than 5\% [12]. The AME formula in question is as follows.

$$
\begin{gathered}
A M E=\frac{|B-A|}{A} \times 100 \%=\cdots \% \\
A M E=\frac{|48-50,4|}{50,4} \times 100 \%=4,7 \%
\end{gathered}
$$

The reference and simulation data contained in Table 4 are then entered into the AME formula. Based on the calculation, the AME value obtained is $4.7 \%$ so that it is greater than the maximum error tolerance of $5 \%$. Therefore, the model is declared valid. The following is the calculation of AME against the data in Table 4.

\subsection{Business as Usual Simulation}

Based on the simulation results that have been declared valid, it is necessary to continue with the Business as Usual (BAU) simulation activity for policy analysis [13]. In this case, a BAU simulation was carried out on Death and Cemetery Land Needs. According to the research objectives, the Cemetery Land Needs is modeled until the 20th week to show future trends. BAU results can be seen in Table 5.

Table 5. Simulation of Business as Usual Cemetery Land Needs

\begin{tabular}{|c|c|c|}
\hline $\begin{array}{c}\text { Week } \\
-\end{array}$ & $\begin{array}{c}\text { Death } \\
\text { (People) }\end{array}$ & $\begin{array}{c}\text { Cemetery Land Needs } \\
\left(\mathbf{m}^{2} / \text { Week }\right)\end{array}$ \\
\hline 1 & 16 & 61,37 \\
\hline 2 & 32 & 121,37 \\
\hline 3 & 48 & 181,37 \\
\hline $\mathbf{4}$ & $\mathbf{6 4}$ & $\mathbf{2 4 1 , 3 8}$ \\
\hline 5 & 80 & 301,38 \\
\hline 6 & 96 & 361,39 \\
\hline 7 & 112 & 421,39 \\
\hline $\mathbf{8}$ & $\mathbf{1 2 8}$ & $\mathbf{4 8 1 , 3 8}$ \\
\hline 9 & 144 & 541,38 \\
\hline 10 & 160 & 601,37 \\
\hline 11 & 176 & 661,35 \\
\hline $\mathbf{1 2}$ & $\mathbf{1 9 2}$ & $\mathbf{7 2 1 , 3 3}$ \\
\hline 13 & 208 & 781,29 \\
\hline 14 & 224 & 841,25 \\
\hline 15 & 240 & 901,20 \\
\hline $\mathbf{1 6}$ & $\mathbf{2 5 6}$ & $\mathbf{9 6 1 , 1 3}$ \\
\hline 17 & 272 & $1.021,06$ \\
\hline 18 & 288 & $1.080,96$ \\
\hline 19 & 304 & $1.140,86$ \\
\hline $\mathbf{2 0}$ & $\mathbf{3 2 0}$ & $\mathbf{1 . 2 0 0 , 7 4}$ \\
\hline
\end{tabular}

Table 5 shows that in week 4 the number of deaths due to COVID-19 is predicted to be 64 people, so the Cemetery Land Needs is $241.38 \mathrm{~m}^{2}$. In the next interval, namely the 8 th week, the estimated number of deaths is 128 people, so it requires a burial area of $481.38 \mathrm{~m}^{2}$. Furthermore, in the 12 th week or third month, the number of deaths is estimated at 192 people and requires a burial ground of $721.33 \mathrm{~m}^{2}$. Then, in the 16th week, it is estimated that there will be 256 deaths, requiring a burial area of $961.13 \mathrm{~m}^{2}$. Finally, in the 20 th week, it is estimated that the death toll will reach 320 people with a burial area of up to $961.13 \mathrm{~m}^{2}$. In addition to being in tabular form, the trend of COVID-19 Positive Population along with Death and Cemetery Land Needs can be illustrated in Fig. 8.

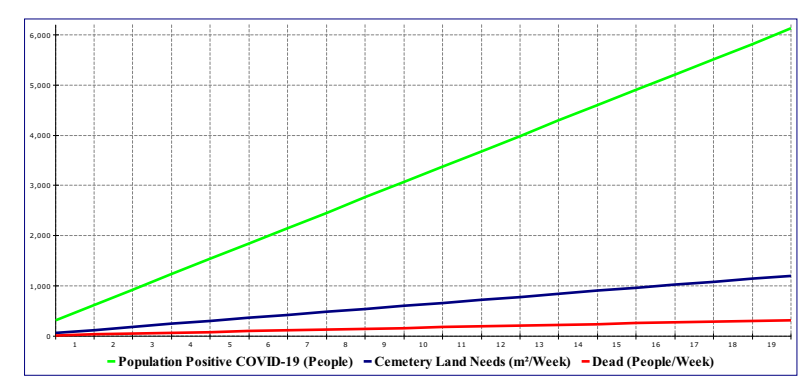

Fig. 8. Comparison of COVID-19 Positive Populations, Deaths, and Cemetery Land Needs

Fig. 6 shows a comparison between the COVID-19 Positive Population, Mortality, and Cemetery Land Needs based on BAU results. The BAU results show that the COVID-19 Positive Population always increases every week. This also has an impact on the increase in Burial Land Demand (blue line) which appears to be twice as high as Death (red line). The graph of the BAU simulation results shows that from week 1 to week 20 it always shows an increase or exponential growth. This shows that this model is in the form of a scenario without government policy or a model that works properly. That is, the value of the intervention model is 0 percent [9].

\section{Conclusion}

Based on the analysis and discussion, it can be concluded that the simulation results show an AME value of $4.7 \%$ or less than $5 \%$ so that the model is declared valid. After being declared valid, a Business as Usual simulation was carried out to model Death and Cemetery Land Needs. The results of the BAU modeling in the 4th week or first month show that the number of deaths due to COVID-19 is estimated at 64 people so that the Cemetery Land Needs is $241.38 \mathrm{~m}^{2}$. Meanwhile, in the 20th week, it is estimated that the death toll will reach 320 people with a burial area of up to $961.13 \mathrm{~m}^{2}$. Trends in Positive COVID-19 Population, Death, and Cemetery Land Needs from week 1 to week 20 based on the graph of the BAU simulation results show that there is always an increase or exponential growth.

Policymakers can use the model to be considered in decision-making because it is valid or feasible. In particular, this model can be used as a reference in preparing Cemetery Land Needs based on the development of COVID-19 Positive Population and Death. Thus, security related to Cemetery Land Needs will ultimately improve national security to prevent conflicts due to fighting over places or the practice of buying and selling burial land for COVID-19 positive bodies. 


\section{References}

1. K. Defense, Jakarta Ministry. Defense of the Republic of Indonesia. (2015)

2. BPS, Statistik Indonesia (Central Bureau of Statistics of the Republic of Indonesia (BPS), 2020)

3. S. Maarif, Thoughts and Ideas: Disaster Management in Indonesia, National Agency for Disaster Management (2012)

4. R. Djalante, J. Lassa, D. Setiamarga, A. Sudjatma, M. Indrawan, B. Haryanto, C. Mahfud, M. S. Sinapoy, S. Djalante, and I. Rafliana, Prog. Disaster Sci. 6, 100091 (2020)

5. T. P. Katadata, Kata Data (2020)
6. Apnews, (2020)

7. J. Post, (2020)

8. W. Mas' udi and P. S. Winanti, Governance for Handling COVID-19 in Indonesia: A Preliminary Study (Gadjah Mada University Press, 2020)

9. I. Umar and I. Dewata, (2017)

10. Hardjosoekarto, Soft Systems Methodology: (All Software Systems Method) (University of Indonesia Publisher (UI-Press) (2012)

11. B. P. Statistik, Sragen BPS (2020)

12. D. D. Suryono and E. S. Pujilestari, J. Segara 15, 179 (2019)

13. R. Z. Surya and M. Gasali, J. Ind. Eng. Manag. Syst. 7, (2017) 